\title{
Construção da cidadania com respeito às diferenças étnico-raciais e culturais: o processo de implementação da lei n. 10.639/03 em uma escola particular da cidade de Paranaíba/MS ${ }^{1}$
}

\author{
Construction of citizenship with respect to ethnic-racial and \\ cultural differences: the process of law enforcement $n$. \\ 10,639/03 in a private school in the city of Paranaiba / \\ MS
}

Diogo da Silva Roiz ${ }^{2}$

\begin{abstract}
Resumo
Pretende-se verificar em que medida o tratamento da história e da cultura africana e afro-brasileira em sala de aula pode propiciar o combate ao racismo, ao preconceito e a discriminação e o respeito às diferenças. Busca-se conferir se este tipo de trabalho pode ser beneficiado com o uso de cenas cinematográficas (filme de conteúdo histórico) e letras de música, no intuito de produzirem "textos geradores", isto é, de provocarem discussões nas aulas; e se esses debates, por sua vez, podem contribuir para a mudança de "consciência histórica" dos educandos.
\end{abstract}

Palavras-chave: interculturalidade. Racismo. Alteridade. Diferenças Étnicoraciais.

\begin{abstract}
It is intended to verify the extent to which the treatment of African and AfroBrazilian history and culture in the classroom can promote the fight against racism, prejudice and discrimination and respect for differences. It seeks to check whether this type of work can benefit from the use of cinematographic scenes (film of historical content) and lyrics of music, in order to produce "generating texts", that is, to provoke discussions in class; and whether these

\footnotetext{
${ }^{1}$ Este trabalho foi desenvolvido no segundo semestre de 2018 em escolas públicas estaduais e particulares da cidade de Paranaíba, no estado de Mato Grosso do Sul. Agradecemos aos professores (Tiago Gonçalves Zandona - História, Vinícius Garcia R. de Souza - Geografia e Arte, Sonia Aparecida Borges da Silva - Português), à coordenação (Marisa Alcalde Vilela) e à direção (Maria Ivete da Cruz Bruno), e aos alunos da Escola do Centro de Estudos Integrados Caminho (CEIC), que participaram do trabalho realizado em sala de aula, entre outubro e novembro de 2018, por meio da parceria entre escola e universidade no programa de extensão: "As leis na escola". Agradeço também a Sueli do Nascimento pela leitura e comentários ao texto.

2 Professor associado aos cursos de Pedagogia e de Ciências Sociais da UEMS, e dos programas de pós-graduação em Educação e do ProfHistória. Doutor em História pela UFPR, onde também concluiu estágio de pós-doutorado em 2015. E-mail: diogosr@uems.br.
} 
debates, in turn, can contribute to the change of "historical awareness" of learners.

Keywords: Interculturality. Racism. Otherness. Ethnic-racial differences.

As escolas não apenas controlam as pessoas; elas também ajudam a controlar o significado. Pelo fato de preservarem e distribuírem o que se percebe como "conhecimento legitimo" [...] as escolas conferem legitimidade cultural ao conhecimento de determinados grupos [...] (Apple, 2008, p. 103-104).

A história da África, dos povos africanos e de seus descendentes no Brasil, até pouco tempo atrás, aparecia como um capítulo secundário e menor nos livros didáticos usados no ensino fundamental e médio brasileiros (Santos, 2017). Há pouco mais de dez anos a lei n. 10.639/03 (alterada pela Lei n. 11.645/08) foi aprovada no Brasil, principalmente em função das reivindicações do movimento social negro (Domingues, 2009, p. 100-122; Santos, 2005, p. 21-37). A lei reconhecia a necessidade de se valorizar a história e a cultura africanas e afro-brasileiras, tornando seu oferecimento obrigatório no ensino fundamental e médio em escolas públicas e privadas no país, com a meta de combater o racismo, a discriminação e o preconceito, de modo a se propor o respeito pelas diferenças étnico-raciais e culturais. A medida legal deveria ser implementada em sala de aula, com base na produção de novos materiais e livros didáticos, preparação docente, e ser direcionada com vistas a um trabalho interdisciplinar, preferencialmente oferecido pelas disciplinas de História, Língua Portuguesa (Literatura) e Artes.

O que se nota é que apesar de ter sido produzido material didático apropriado à condução dos trabalhos em sala de aula e ao ensino dos conteúdos curriculares específicos, os professores não foram suficientemente preparados para implementar essas discussões e programa de estudos, por meio de um trabalho interdisciplinar (Borges, 2016; Roiz, Santos, 2018). Em outras palavras, a lei é trabalhada em sala de aula em função de sua obrigatoriedade, muito mais num formato de condução disciplinar (sem contatos e relações com as outras disciplinas), mas não de forma a propiciar o combate efetivo ao racismo e o respeito às diferenças, por intermédio de um 
trabalho interdisciplinar continuado entre os ciclos de aprendizado escolar (Borges, 2016).

O que se pretende com este texto é fornecer material didático apto à execução de um trabalho interdisciplinar, não somente entre as disciplinas de História, Língua Portuguesa e Artes, mas em condições de demonstrar a importância de se agrupar a esse elenco a disciplina de Geografia. Ao mesmo tempo, pretende-se verificar em que medida o tratamento da história e da cultura africana e afro-brasileira em sala de aula pode propiciar o combate ao racismo, ao preconceito e a discriminação e o respeito às diferenças ${ }^{3}$. Por fim, busca-se conferir se este tipo de trabalho pode ser beneficiado com o uso de cenas cinematográficas (filme de conteúdo histórico) e letras de música, no intuito de produzirem "textos geradores" na expressão de Marcos Napolitano (2009, p. 10-31), isto é, de provocarem discussões nas aulas; e se esses debates, por sua vez, podem contribuir para a mudança de "consciência histórica" (Rüsen, 2010) dos educandos.

Para Marcos Napolitano (2009, p. 10-31), o "texto gerador" constitui um instrumento didático, com o qual os profissionais podem estabelecer um "fio condutor" entre as discussões efetuadas em sala de aula. Aventa-se esse pressuposto pela possibilidade de: "a) O filme pode ser um "texto" gerador de debates articulados a temas previamente selecionados pelo professor"; e "b) O filme pode ser visto como um documento em si" e ser "analisado e discutido como produto cultural e estético que veicula valores, conceitos, atitudes e representações sobre a sociedade, a ciência, a política e a história." (Napolitano, 2009, p. 20). O profissional deve, contudo, esclarecer ser o filme constituído por um tema conjugado a um roteiro, que tem como meta fornecer ao público uma representação cinematográfica, em função de parâmetros propostos pelo mercado consumidor, na expectativa de maximização de lucros; que sua linguagem é intermediada por questões socioculturais e

\footnotetext{
${ }^{3}$ Para a compreensão de por que essas questões são tão caras a sociedade brasileira, ver: Guimarães, 1999, 2000, 2006. Para uma análise histórico-sociológica dos dilemas brasileiros, ver: Souza, 2011, 2015, 2017, 2018. Para uma análise sobre o impacto dos debates póscoloniais, que mostraram o nivel das desigualdades humanas em função da cor, da renda, do acesso a cultura e a educação, ver: Gomes, Domingues, 2014; Gilroy, 2007.
} 
políticas de um dado momento histórico; que sua realização é o produto de uma circunstância sociocultural específica, na qual a relação imagem, público e enredo são profundamente estudadas para a definição da trama, antes mesmo de sua produção ser realizada. Além disso, o profissional precisa ter clareza de que:

[...] uma premissa básica para transformar a experiência social e cultural do cinema, que começa antes e vai além da sala de aula, em uma experiência de conhecimento escolar. Todo filme, ficção ou documentário, é resultado de um conjunto de seleções, escolhas, recortes, perspectivas, que envolve um leque de profissionais e de interesses comerciais, ideológicos e estéticos. Isso implica afirmar que todo filme documental não é a representação direta da realidade, e que todo filme ficcional não está desligado da sociedade que o produziu. O trabalho escolar com o cinema deve ter em vista esta natureza da representação e da encenação cinematográficas.

Outra premissa importante é entender o cinema como uma linguagem artística, com suas regras de expressão, aparatos técnicos, gêneros e estilos, tradições narrativas. Um filme, ficcional ou documental, não se resume ao seu tema (a história contada) ou ao texto verbal que veicula (na forma de diálogos, narrações em off ou legendas). Mais importante é a maneira como se aborda e conta a história veiculada pelo filme e em que situações filmicas os diálogos e textos verbais estão colocados na seqüência de cenas. (Napolitano, 2009, p. 12).

Ao tomar esses cuidados metodológicos, o profissional pode fazer com que o filme seja um "texto gerador" e, portanto, propício a fomentar as discussões em sala de aula, ao servir também como complemento aos livros didáticos.

Para embasar esse estudo tivemos também por base as indicações teórico-metodológicas de Bernard Charlot (2013, 2013b) e Jörn Rüsen (2014, 2015). De acordo com o primeiro a "educação é política" entre outras razões porque não há processos de ensino-aprendizado que não sejam dinâmicos nas relações professor/aluno, cidadão/sociedade ou sociedade civil/Estado. A pesquisa educacional tende a possuir, por isso, uma dupla função: 1. primeiro a de fornecer subsídios para a elaboração de uma avaliação consistente das práticas educativas em vigor, de modo a permitir a formulação de diagnósticos para corrigir eventuais fragilidades em sua execução; 2. depois a de propiciar perspectivas que venham a possibilitar uma intervenção direta no cotidiano escolar e nos processos de ensino-aprendizagem. Para Charlot (2013b, p. 178), por ser "a educação, indissociavelmente, construção de si mesmo e apropriação do mundo humano, ela é um movimento de dentro alimentado 
pelo que o educando encontra fora de si mesmo", razão pela qual a "escola deve assegurar uma mediação entre a criança [e os adolescentes] e os modelos sociais" (Charlot, 2013, p. 390).

Os processos pelos quais os indivíduos passam para construir suas "visões de mundo" e dar sentido as suas ações constituem, para Rüsen (2014), fator decisivo para definir suas atitudes diante da vida, da sociedade e do mundo. E a escola é um lugar determinante para interiorização desses processos, fazendo com que os indivíduos aprendam a sair de suas crises de orientação existencial, por intermédio da compreensão dos processos históricos. O conhecimento do passado lhes fornecerá meios para suas tomadas de decisão no presente. É por meio da História que os indivíduos constroem suas identidades socioculturais. Para ele, a compreensão da História e o entendimento do funcionamento de seus processos (que são a sintese de múltiplas vontades, expectativas e disputas pelo poder), podem amparar os sujeitos ao indicar num movimento de análise "do presente para o passado", o que tornou possível aquele presente histórico e não outro; num segundo movimento, complementar e articulado ao primeiro, indo do "passado para o presente", revelar aos indivíduos o que fundamentou a constituição de suas crises de orientação existencial, dando-lhe a percepção de que a História é um processo pluridimensional (e não único), o que possibilita igualmente serem feitas diversas leituras do passado.

É por essa razão que a "consciência histórica" (em seus variados tipos: tradicional, exemplar, critica ou genética) é uma experiência do tempo (vivida ou não pelos indivíduos, imersos no processo que culminou naquele presente histórico) e intenção no tempo (cujas múltiplas vontades geraram uma síntese possivel) para fundamentar o agir humano. Por isso, os meios pelos quais os alunos passam a definir suas escolhas e "darem sentido a cultura que herdaram" passa a ser um dos quesitos decisivos de uma formação que é "a capacidade de responder racionalmente às perguntas [...] por orientação que se colocam no contexto das situações atuais da vida" (Rüsen, 2014, p. 78), uma vez que todas "as dimensões de sentido são configuradas comunicativamente e se interpenetram" (Rüsen, 2015, p. 276) no espaço 
social com o qual os indivíduos estão em constantes processos de sociabilidade, sendo instados a tomarem decisões e se posicionarem diante do mundo em que vivem.

De acordo com Rüsen (2001) é por intermédio de narrativas que os individuos racionalizam as experiências do passado, dando sentido aos processos históricos, com vistas a subsidiar suas carências de orientação no presente e favorecer suas tomadas de decisão. Nas narrativas é que se observa que tipo de "consciência histórica" mediou a interpretação dos processos históricos efetuada pelos sujeitos. Para este autor, a narrativa histórica "está ligada ao ambiente da memória", por que "mobiliza a experiência do tempo passado, a qual está gravada nos arquivos da memória, de modo que a experiência do tempo presente se torna compreensivel" (Rüsen, 2010, p. 97). É justamente por isso que os sentidos podem ser configurados em diferentes tipos de "consciência histórica". Neles existiria uma tradicional, outra exemplar, uma crítica e outra genética. Cada uma delas faz leituras e interpretações peculiares sobre as relações: passado, presente e futuro, dando sentidos e direcionamentos distintos ao processo histórico - vivido ou não pelo sujeito que a empreende em sua narrativa.

Sob esse aspecto, seria possivel acompanhar o movimento deste pensamento, e do tipo de "consciência histórica" a ele conferido, ao se analisar um conjunto de narrativas produzidas pelos educandos a respeito de uma dada temática? Ao se correlacionar um tipo de conhecimento histórico já dado e ensinado aos alunos (tese), novas possibilidades de leitura e interpretações do passado (antítese) os discentes teriam a condição necessária para produzir novas sinteses sobre a história do Brasil e da África? Com esse tipo de conhecimento em mãos seriam os alunos capazes de visualizar preconceitos, combater o racismo e respeitar as diferenças étnico-raciais e culturais? Estas foram as questões que nortearam o direcionamento de nossa análise dos dados alcançados com o trabalho efetuado em sala de aula, com alunos e alunas de uma escola situada na cidade de Paranaíba, no estado de Mato Grosso do Sul. 


\section{Os procedimentos metodológicos e as fontes pesquisadas}

Eu tenho 14 anos e acho que sou muito novo para poder falar sobre a história de minha vida. Desde criança, eu sempre fui brincalhão, e gosto muito de me relacionar com as pessoas. Gosto muito dos meus pais, eles são muito importantes em minha vida. Foi com eles que eu aprendi sobre a vida, as pessoas, e suas lições me ensinam a me comportar e formar meu caráter. Eu quero esclarecer logo de início sobre minha vida, é que eu sou testemunha de Jeová. Então há coisas que eu não faço como participar de aniversários, ir a festas noturnas, ou beber qualquer tipo de bebida alcoólica. Na minha escola eu me esforço para poder ser diferente, mas sei que isso é dificil, pois até meus amigos não entendem muito bem minhas escolhas. Achei muito bacana este tipo de trabalho, por me acrescentar coisas que eu pouco sabia, como muitos dos preconceitos vividos pelos negros no passado, não são muito diferentes das que recebem pessoas como eu ao praticarmos nossas escolhas religiosas. As pessoas são muito preconceituosas em nosso país, com os velhos, com as mulheres, com os deficientes, com os pobres, e começo a ver que com os negros também é muito dificil. Na escola, eu me preocupo em tirar boas notas. Acontece que eu tenho uma boa dificuldade em matemática, mas nas demais disciplinas eu vou bem, principalmente em História. Acho que a disciplina é minha preferida por ler muito a Bíblia e ver como a História, e as histórias que as escrituras contam, serve para nos orientar ainda hoje. Mas resumindo é isso, sou um garoto que gosta de brincar, conversar com os outros, mas sei que tudo no limite, nem tudo é brincadeira, e claro pensando (ou tentando pensar) no próximo (9a14).

Os procedimentos metodológicos que ampararam a execução do trabalho em sala de aula foi o resultado de análises da aplicação da lei $\mathrm{n}$. 10.639/03 em mais de dez escolas, distribuídas entre quatro cidades, em dois estados diferentes (Roiz, Santos, Teixeira, 2010; Roiz, 2016, 2018; Roiz, Santos, 2018, 2018b). Por mais de dez anos foram feitas experiências com o uso de cenas de filmes, documentários, curta-metragens, letras de música, imagens (fotos, quadros, desenhos) e interação com páginas da Internet (com foco em questões sobre a história e a cultura africana e afro-brasileira). Aos poucos, notou-se a necessidade de se amparar em conceitos, teorias e metodologias, que nos foram sendo subsidiados pelos textos de Jörn Rüsen $(2010,2012,2014)$ e Paulo Freire $(2003,2011,2017)^{4}$. Ainda que o foco deste

\footnotetext{
${ }^{4}$ Note-se que Maria Auxiliadora Schmidt e Tânia Maria Braga Garcia $(2003,2005)$ viram a possibilidade de articular Freire e Rüsen em pesquisas no campo da educação histórica. Seus estudos deram prosseguimento com as contribuições de Barca e Urban, em: Schmidt, Barca,
} 
artigo esteja em Rüsen, não quer dizer que o trabalho de Freire seja menos promissor neste tipo de estudo (Roiz, 2018). Foi com base nas interações entre teoria e prática, erros e acertos, que buscamos sintetizar a possibilidade de execução do trabalho interdisciplinar para mediar a aplicação da lei em sala de aula, no quadro número 1 que se segue abaixo:

\section{Quadro - 1: Distribuição do trabalho interdisciplinar e seus conteúdos}

\begin{tabular}{|c|c|c|c|}
\hline História: & Lingua Portuguesa: & Artes: & Geografia: \\
\hline $\begin{array}{l}\text { 1) O que o Brasil adquiriu } \\
\text { com a África a partir do século }\end{array}$ & $\begin{array}{l}\text { 1) Como você contaria a } \\
\text { história de sua vida? }\end{array}$ & $\begin{array}{l}\text { 1) O que você sabe sobre } \\
\text { a arte africana? }\end{array}$ & $\begin{array}{l}\text { 1) O que você sabe sobre } \\
\text { o continente africano? }\end{array}$ \\
\hline XVI, e o que a Africa negociou & & & \\
\hline com o Brasil? & 2) Conte a história de vida & 2) O que você sabe sobre & 2) O que você sabe sobre \\
\hline $\begin{array}{l}\text { 2) Qual a contribuição dos } \\
\text { africanos } \mathrm{e} \text { dos afro- }\end{array}$ & admira. & & $\begin{array}{l}\text { escravos da África para } \\
\text { as Américas? }\end{array}$ \\
\hline $\begin{array}{l}\text { descendentes na formação da } \\
\text { sociedade brasileira? }\end{array}$ & $\begin{array}{l}\text { Filme: Escritores } d a \\
\text { liberdade }^{* *}\end{array}$ & & \\
\hline Documentário: Vista minha & Trabalhar com: & Trabalhar com a: & Trabalhar com: \\
\hline $\begin{array}{l}\text { Música: Negro Drama e/ou } \\
\text { Faroeste caboclo }\end{array}$ & $\begin{array}{l}\text { Navio Negreiro e } \\
\text { Fragmento do romance } A \\
\text { moreninha }\end{array}$ & $\begin{array}{l}\text { Produção artística (fotos, } \\
\text { quadros, esculturas, } \\
\text { roupas, músicas) da } \\
\text { África }\end{array}$ & $\begin{array}{l}\text { A distribuição geográfica } \\
\text { do continente africano a } \\
\text { partir do final do século } \\
\text { XIX }\end{array}$ \\
\hline Cena dos filmes: Amistad e & Fragmento do romance: & Trabalhar com: & Trabalhar com: \\
\hline Quilombo & $\begin{array}{l}\text { Memórias póstumas de Brás } \\
\text { Cubas ou Dom Casmurro }\end{array}$ & $\begin{array}{l}\text { Produção artística afro- } \\
\text { brasileira }\end{array}$ & A distribuição do tráfico \\
\hline Música: Palmares & E cena do Filme & & $\begin{array}{l}\text { de escravos entre a } \\
\text { África e o Brasil no } \\
\text { século XIX }\end{array}$ \\
\hline $\begin{array}{l}\text { Cena dos filmes: Chica da } \\
\text { Silva e Cafundó }\end{array}$ & $\begin{array}{l}\text { Fragmento do romance: } \\
\text { Macunaima e cena do filme }\end{array}$ & $\begin{array}{l}\text { Trabalhar com a: } \\
\text { Produção artística } \\
\text { brasileira e identificar a } \\
\text { contribuição africana e } \\
\text { afro-descendente }\end{array}$ & $\begin{array}{l}\text { Trabalhar com o: } \\
\text { Atlas Geográfico de Mato } \\
\text { Grosso do Sul e seus } \\
\text { municipios e identificar } \\
\text { em quais houve } \\
\text { escravidão }\end{array}$ \\
\hline $\begin{array}{l}\text { Cena do filme: Uma onda no } \\
\text { ar }\end{array}$ & $\begin{array}{l}\text { Fragmento do romance: } \\
\text { Cidade de Deus e cena do } \\
\text { filme }\end{array}$ & $\begin{array}{l}\text { Trabalhar com a: } \\
\text { Produção artística } \\
\text { recente no Brasil e na } \\
\text { África e identificar } \\
\text { aproximações e } \\
\text { diferenças }\end{array}$ & $\begin{array}{l}\text { Solicitar que o aluno } \\
\text { pesquise no bairro onde } \\
\text { mora se há famílias } \\
\text { afro-descendentes, e } \\
\text { quantas casas ele } \\
\text { consegue enumerar com } \\
\text { esse perfil }\end{array}$ \\
\hline
\end{tabular}

Fonte: Dados e síntese do projeto desenvolvido em sala de aula (Cf. Roiz, Santos, Teixeira, 2010; Roiz, Santos, 2018).

* Deve ser passado cenas de filmes de 5 a 10 minutos; a exceção pode ser feita com Vista minha pele, que pode ser visto na integra (por ter apenas 24 minutos de duração).

2009, 2009b, 2015; Schmidt, Urban, 2014; Schmidt, Garcia, 2013, 2011, 2008. No entanto, vale destacar, estas não procuraram pensar os niveis e tipos de consciência histórica, que podem ser auferidos pelos educandos no processo de ensino-aprendizado (Roiz, 2018). Todavia, a leitura de seus textos foi fundamental para avançarmos em nossa análise e pensarmos na possibilidade de execução deste tipo de pesquisa em sala de aula. 
** Filme de 2007, com $2 \mathrm{~h} 15 \mathrm{~min}$. Pode ser passado na íntegra ou em parte(s) de acordo com o planejamento docente que, aliás, pode ou não incluí-lo no trabalho de acordo com as respostas das questões iniciais.

Pretendemos apresentar neste texto, alguns resultados auferidos com esse trabalho em sala de aula, que ocorreu entre outubro e novembro de 2018. Nota-se, pelo quadro acima, a distribuição de conteúdo entre as disciplinas de História, Língua Portuguesa, Artes e Geografia. Entre os anos letivos cada disciplina contava com 2 a 3 aulas semanais; porém, para a execução do projeto foi reservada apenas 1 para não comprometer as discussões específicas dos cadernos de conteúdo do sistema de ensino ao qual a escola está vinculada. Atente-se que era comum a todas as disciplinas: 1 - ao final de cada aula solicitar ao aluno a produção de um texto; 2 - depois do trabalho realizado em sala de aula deveria ser repetida as duas questões da primeira aula (indicada no quadro 1); 3 - ao final do trabalho realizado, fazer uma roda de conversa com os alunos e identificar o que aprenderam. O resultado das aulas, das rodas de conversa e das produções textuais pode ser avaliado por meio do questionário a que os alunos deveriam responder, e que se segue abaixo:

1 - Como você se autodeclararia em termos de cor e personalidade?

2 - Depois de acompanhar o trabalho desenvolvido em sala de aula, como você vê a questão do racismo e do negro na história do Brasil?

3 - De que maneira você passou a observar a história do Brasil e a participação do negro e do afro-descendente na formação da sociedade brasileira?

4 - Quais os pontos positivos e negativos que você destacaria no trabalho que foi desenvolvido em sala de aula pelas disciplinas de História, Língua Portuguesa, Artes e Geografia?

5 - O que você achou e que considerações poderia fazer a respeito do trabalho feito pelo(a) professor(a) de História, de Português, de Geografia e de Artes?

O trabalho foi executado em uma escola particular durante os meses de outubro e novembro de 2018, como frisamos acima. A participação de professores, da coordenação e da direção foi fundamental para a realização das atividades. Participaram do trabalho alunos de um sétimo (com 22 alunos), um oitavo (com 18) e um nono (com 31) ano do período matutino, com um total de 71 discentes. Após a realização de todas as atividades, chegou-se ao total de 71 questionários iniciais respondidos para a matéria de 
Lingua Portuguesa, 43 para a de História, 28 para as Artes e 18 para a de Geografia, totalizando 160 questionários iniciais produzidos entre as três salas de aula - não houve tempo hábil para ser repetido este questionário no final do trabalho realizado pelos docentes.

Com relação às produções textuais tivemos 57 em Língua Portuguesa, 16 em História, 5 em Artes e 2 em Geografia, totalizando 80 produções textuais. O baixo número de produções textuais se deveu aos feriados (do mês de novembro) e ao choque com o calendário escolar de provas do último bimestre, que comprometeu a participação ativa dos discentes quanto às produções textuais. Esta foi uma das dificuldades que enfrentamos ao trabalhar com uma escola particular; admitimos, porém, ter sido desafiador e ter mostrado como é importante pensar o planejamento do trabalho e suas especificidades entre escolas públicas e privadas. Coisa semelhante ocorreu com o número de questionários finais entregues para avaliarmos o resultado do trabalho entre os discentes, que resultou em 29 - com 3 vindos sem nenhuma resposta e 6 parcialmente respondidos.

Apesar das restrições para efetuarmos a análise, como veremos abaixo, o material apresentado foi rico, promissor e revelador em muitos sentidos, inclusive no que diz respeito à importância do estudo da história e da cultura africana e afro-brasileira no Ensino Fundamental II (como a epígrafe que abre este item nos revela), momento em que os alunos começam a desenvolver com maior propriedade abstrações, interpretações sobre a realidade, o presente e passado, às vezes colocando-se até como sujeitos no processo histórico.

Antes de passar ao estudo deste material é importante que façamos alguns apontamentos prévios em relação ao grupo de alunos que participou das atividades realizadas em sala de aula. Com base no registro dos discentes ${ }^{5}$ foi possivel identificar a seguinte distribuição de alunos, no quesito cor, nas salas de aula: 1 . no sexto ano havia 10 alunos brancos e 7 pardos; 2 . no sétimo ano, 16 brancos, 5 pardos e 1 negro; 3. no oitavo ano, 9 brancos e 9 pardos; 4. no nono ano, 20 brancos, 10 pardos e 1 negro. Mesmo não tendo sido aqui agrupado o sexto ano, a sua indicação serve para mostrar a distribuição dos

\footnotetext{
${ }^{5}$ Que se encontra arquivada na secretaria da escola.
} 
alunos do Ensino Fundamental II desta escola (com 55 brancos, 31 pardos e 2 negros, totalizando 88 discentes). Para os três anos letivos que participaram das atividades, tivemos 45 brancos, 24 pardos e 2 negros. Não foi possível comparar este resultado com a autodeclaração dos alunos em todos os casos, em função do baixo número de questionários finais respondidos, mas como veremos abaixo, mesmo assim foi revelador o resultado apresentado.

A faixa etária dos alunos do nono ano (26) era de 14 anos (4 com 15 e 1 com 13, embora 3 deles não informassem a idade no questionário). Alguns informam a profissão do pai (3 fazendeiros, 1 madeireiro, 1 caminhoneiro e 1 entregador) e da mãe (3 professoras), mas a maioria não informou (23 não indicaram a da mãe e a do pai, 5 da mãe e 3 do pai). Nenhum deles teve a preocupação de informar a cor no questionário prévio (de Língua Portuguesa). A maioria dos alunos é originária de Paranaíba, ou de cidades vizinhas poucos vieram de locais mais distantes, ou mesmo de outros estados. Quando foram instigados a contar a história de alguém que admiravam: 11 falaram um pouco da história do pai; 11 da mãe; 3 de familiares; 3 da avó e 1 do avô; 1 do tio e 1 do primo. Veja-se o exemplo de 9a6, parda, ao contar a história de sua avó:

$\mathrm{Na}$ verdade eu admiro várias pessoas de minha família, por seus exemplos de superação. Mas em especial minha avó materna, que tem uma grande história de superação, que eu admiro muito. Desde criança sofreu por dificuldades financeiras. Ela veio de uma familia que vivia na miséria e ao longo dos anos ela vem passando por várias batalhas, como: há 10 anos sofreu com a perda de sua mãe e de seu pai. Depois sofreu com a enfermidade do tio, que foi baleado após ajudar um homem que pedia esmola e hoje é paraplégico graças as terapias e aos centros de reabilitação. Mas, até isso foi muito difícil, por que custou muito dinheiro e ela não tinha.

Para minha avó conseguir o dinheiro não foi fácil, ela teve que sacrificar muito. Fez bingos, almoços beneficientes, trabalhava em vários turnos diferentes. Hoje em dia ela sofre com o meu avô que aos poucos está perdendo a visão, e precisa de muito cuidado, assim como meu tio. Esse é o motivo para eu admirá-la. Pois, ela enfrenta todos os dias batalhas que não podem ser vencidas. $\mathrm{E}$ eu amo a sua frase, frase esta que ela me fala sempre que vê que não estou muito bem: "Enquanto eu tiver 1\% de chance eu vou ter $100 \%$ de fé para superar as adversidades da vida".

No oitavo ano, 8 alunos informaram que estavam com 13 anos, 1 com 14 e 8 não responderam. Apenas em 1 caso foi informada a profissão do pai (agrônomo) e 1 da mãe (professora); 15 não informaram do pai e da mãe; 1 da mãe e 1 do pai. Não tiveram também a preocupação de informar a cor. A 
origem do público também não diferiu do nono ano; mas no oitavo, 9 contaram a história do pai, 3 da mãe, 3 da avó, 1 do avô e 1 do bisavô. Note-se a sensibilidade de 8a19, parda, ao falar de seu pai:

Eu vou contar a história de meu pai, mesmo ele não sendo presente, não me ajudando, não sendo o pai que eu preciso no momento, eu amo ele, e me orgulho muito dele, pois independente de qualquer coisa, ele nunca deixou faltar nada em casa, sempre mantém as coisas corretas em casa, trabalha o dia inteiro e fica muito tempo fora de casa.

No sétimo ano, 8 alunos declararam estar com 12 anos; 3 deles, com 13; 10 não informaram. Apenas 1 informou a profissão da mãe (professora de música), 21 não informaram a profissão do pai e da mãe, e 1 do pai. A origem do público também não diferiu dos outros dois anos letivos, mas no sétimo, houve preponderância em se contar a história da mãe (7) ou da avó (4); apenas 3 falaram do pai, 1 do avô, 1 dos pais, 1 dos avós, 1 do tio e 2 da irmã. Vejase o caso de 7 a3, branca, ao falar de sua mãe:

[...] desde pequena trabalhou muito, viveu sem a mãe e com pouca presença do pai, mas sempre foi uma ótima aluna na escola. Infelizmente se envolveu com meu pai, quando era muito nova, e isso a prejudicou muito, mas nunca desistiu, sempre trabalhou muito e deu o de melhor para sua filha (eu). Ela é uma mulher guerreira, que não desiste nunca, e por me criar praticamente sozinha eu admiro muito minha mãe, ela é meu exemplo.

O que justificava as variações apresentadas entre o oitavo e o sétimo ano? $\mathrm{Na}$ análise dos questionários, vimos que contar a história da mãe ou do pai foi o resultado da separação do casal e de quem ficou com a guarda dos filhos. Embora pareça não nos indicar muito, veremos abaixo que os dados apresentados até aqui são fundamentais para entendermos como os alunos contam suas histórias, percebem sua "realidade" e interagem com os outros na sociedade em que vivem e olham para o passado.

\section{As interpretações sobre a história do Brasil e o combate ao racismo}

Minha avó materna [...] é uma pessoa muito importante na minha vida. Eu admiro ela porque na sua trajetória de vida passou por muitas coisas dificeis. Quando tinha entre 9 e 11 anos perdeu seu pai, meu bisavô, que teve um infarto. Depois disso, minha avó teve que ir morar na casa da avó paterna [...]. A avó da minha avó era uma espanhola judia, que veio para o Brasil no final do século XIX. A casa dela era muito grande, com vários 
quartos e empregados - acho até que teve escravos. Minha avó foi morar com ela porque a mãe dela [...] teve que passar um tempo trabalhando em outra cidade e levou somente os irmãos mais novos [...]. Nesse meio tempo, minha avó teve oportunidade de brincar e estudar. Ela não estudava antes por falta de condições financeiras. Ela só pôde estudar graças a avó dela que pagou todos seus estudos. Ela estudou até o $4^{\circ}$ ano, até que minha bisavó voltou para casa e aí voltou tudo como era antes na vida dela. Entre 1945 e 1950 quando minha avó já era adulta, conheceu meu avô [...] e se casaram. Tiveram seis filhos e entre eles estava minha mãe [...]. A infância de minha mãe e de meus tios foi como qualquer outra, com coisas boas e ruins. Quando minha avó começou a perder seus filhos ela ficou arrasada, e no final dos anos 1990 meu avô morreu. Hoje gosto muito de ouvir suas histórias, e o que contei é o que guardo na minha memória... (7a2, branco).

A disciplina de História deve, segundo Rüsen (2010), dar meios para que os alunos formem competências de experiência (a habilidade de ter experiências temporais, relacionando passado e presente), de interpretação (capacidade de dar significado as experiências temporais) e de orientação (capacidade de utilizar a temporalidade, com seu conteúdo de experiência, para os propósitos de orientação da vida). Para este autor, quando os discentes são capazes de usar tais competências, eles demonstram como são alinhadas em suas narrativas que "tem a função geral de servir para orientar a vida prática no tempo", por "conferir uma perspectiva temporal interna e externa à vida prática" - nesse ponto a epígrafe acima diz muito. É por isso que a "consciência histórica vem à tona ao contar narrativas, isto é, histórias, que são uma forma coerente de comunicação, pois se referem à identidade histórica de ambos: comunicador e receptor" (Rüsen, 2010, p. 80). Além disso, por óbvio que pareça, nunca é demais repetir, com Rüsen, que "aprender é um processo dinâmico em que a pessoa que aprende é transformada" (Rüsen, 2010, p. 82).

Com essa peculiaridade, as narrativas, que nesse caso têm um perfil histórico, podem também indicar o tipo de "consciência histórica" que permeia o olhar dos alunos sobre o transcurso da temporalidade. Para ele, a função prática da consciência histórica é conferir "à realidade uma direção temporal, uma orientação que pode guiar a ação intencionalmente, através da mediação da memória histórica" (Rüsen, 2010, p. 58). Para o autor de História vivida, o tipo tradicional de consciência histórica não pressupõe outras formas porque é o começo e sem ela não é possivel a mudança para outras. De acordo com 
ele, a "experiência de ensinar história em escolas indica que as formas tradicionais de pensamento são mais fáceis de aprender", mas a "forma exemplar domina a maior parte dos currículos de história", enquanto as "competências críticas e genéticas requerem um grande esforço por parte dos docentes e do aluno" (Rüsen, 2010, p. 74).

Ao longo dos anos temos procurado refletir em que medida uma nova leitura do passado pode mudar o conhecimento herdado pelos alunos e a eles possibilitado novas sínteses sobre a história da sociedade brasileira (Roiz, Santos, Teixeira, 2010). Com base nos casos já estudados em cidades e estados diferentes temos notado que 1 em cada 10 alunos do Ensino Fundamental II tem alcançado as competências da experiência, da interpretação e da orientação, mas apenas 1 em cada 20 tem começado a dar indícios de transitar entre um tipo de "consciência histórica" crítica e/ou genética (Roiz, 2018, 2018b; Roiz, Santos, 2018, 2018b). Por isso mesmo, acrescentar a esse rol de estudos novos casos é importante não somente para se comparar situações de ensino, mas também procurar construir possiveis formas de aprendizado que permitam ao aluno ter meios para repensar seu conhecimento do passado e, nesse caso, igualmente o tipo de "consciência histórica" que embasa sua competência narrativa (Cerri, 2011).

Os desafios do ensino da história e da cultura africana e afro-brasileira em sala de aula nos oferecem um ambiente propício para situar a problemática e trabalhar com ela com os educandos. Para que isso seja feito o professor de história deve, antes de qualquer coisa, procurar observar o conhecimento do passado herdado pelos alunos em anos anteriores de estudo. O questionário inicial (indicado no quadro 1) tem justamente essa função. Com essa percepção o docente deve começar problematizando a ideia de "democracia racial" - proposta por Gilberto Freire nos anos $1930^{6}$ - com base em letras de música como: "Negro drama" e "Faroeste caboclo", e com o curtametragem: "Vista minha pele"7. Ao se problematizar o presente e instigar os

\footnotetext{
${ }^{6}$ Para maiores detalhes sobre essa questão, ver: Roiz, Santos, Teixeira, 2010.

7 A sequência completa de letras de música é: "Negro drama", "Faroeste caboclo" e "Palmares". A de cenas de filmes: Amistad. Direção: Steven Spielberg, 1997; Quilombo. Direção: Carlos Diegues, 1984; Xica da Silva. Direção: Carlos Diegues, 1976; Gaijin: Caminhos da
} 
alunos a revisitar o conhecimento do passado, seguindo o movimento indicado por Rüsen $(2010,2012)$ para subsidiar as carências de orientação existencial no presente, é possível fazer os discentes pensarem teses e antiteses sobre a história do Brasil. Temos observado, porém, maior dificuldade em construir novas sinteses (Roiz, 2018; Roiz, Santos, 2018). Com isso, o professor pode explorar novos caminhos para pensar a história do Brasil e situar aos discentes o papel e a presença do negro e do afro-descendente na formação da sociedade brasileira, com as cenas dos filmes: "Amistad", "Quilombo", "Xica da Silva", "Cafundó" e "Uma onda no ar" na interpretação do processo histórico - e, nesse duplo movimento, evidenciar aos alunos continuidades e rupturas, avanços e recuos, presentes em nossa história9 .

Dito isto, é possivel avaliar o trabalho realizado em sala de aula com a produção textual dos alunos. Com base nos 43 questionários iniciais entregues pelos discentes do sétimo, oitavo e nono ano ${ }^{10}$, é possível observar que 27 deles têm conhecimentos básicos sobre o que o Brasil adquiriu da África, a partir do século XVI (mas não o que a África recebeu do Brasil), e a respeito da contribuição dos africanos e afro-descendentes na formação da sociedade brasileira. Muitos deles (8) informam a importância dos "costumes e culturas", mas não conseguem relacionar o tráfico de escravos com a vinda destes valores para o Brasil. Para 5 deles, o território que formará o Brasil adquiriu apenas "compra de escravos". Para 7a15, branca, a maior

liberdade. Direção: Tizuka Yamasaki, 1980; Cafundó. Direção: Paulo Betti/Clóvis Bueno, 2005; Heróis de todo o mundo. Direção: Jorge Henrique Cavalcante Fiel; Besouro. Direção de João Daniel Tikhomiroff, 2009; Uma onda no ar. Direção: Helvécio Ratton, 2002; Vista a minha pele. Direção: Joel Zito Araújo, 2003. O VHS do Kit da cor da cultura: "Os grandes heróis de todo mundo", pode ser trabalhado em sala de aula para complementar esse programa de estudos com as letras de música e as cenas dos filmes. Não o incluímos nesse programa de trabalho em função das escolhas por um trabalho interdisciplinar e do tempo de que dispúnhamos para desenvolver o trabalho em sala de aula (já explicado em outro item do texto). Veja-se o texto de Roiz, Santos e Teixeira (2010, p. 209-230), que indica como esse vídeo pode ser articulado no planejamento do trabalho docente.

${ }^{8} \mathrm{O}$ rol de cenas de filmes pode ser ampliado de acordo com o tempo disponível para a execução do trabalho em sala de aula. Aqui, filmes e músicas foram planejados para um trabalho a ser feito entre outubro e novembro, mas como veremos, ainda assim o tempo foi insuficiente para desenvolver plenamente a proposta com os alunos. Para outras tentativas já feitas em sala de aula, ver: Roiz, Santos, 2018, 2018b.

9 Veja-se sobre tal questão: Souza, 2011, 2015, 2017, 2018.

10 Tomamos aqui a amostra em seu conjunto porque muitos alunos não se identificaram. 
contribuição de africanos e afro-brasileiros foi possibilitar a formação de "uma sociedade mais diversificada, influenciando, inclusive, em hábitos alimentares e técnicas para a agricultura"; porém, além "de coisas boas, eles também 'sofreram' muitos preconceitos, torturas e até morte, por sua condição de escravo". Para 7a11, parda, quando "eles vieram para o Brasil se misturaram com outras etnias já existentes aqui, como o índio e os europeus, fazendo acontecer a miscigenação, mas também vieram com eles culturas, costumes, hábitos alimentares, vestimentas e tradições religiosas diferentes".

Após as discussões iniciais o docente passou a trabalhar com as letras de música e as cenas dos filmes. Veja-se, por exemplo, a reflexão que nos apresentou 7a14, com base em "Vista minha pele":

Como seria a história dos escravos se eles tivessem sido brancos e não negros? Como seriam as coisas se tudo que tivesse acontecido fossem invertidas, e os africanos tivessem escravizado os europeus?

A história seria completamente diferente. Não sei como seria contada nas escolas. Mas acho que a valorização que é feita sobre as culturas seria totalmente diferente. Acho que seriamos mais fracos pela falta de melanina, e teriamos muito mais dificuldade de ficar expostos ao sol. Acho que os indices de câncer de pele seriam altíssimos em nossa população. O preconceito pela cor de pele seria diferente e quem teria que lutar por direitos iguais seriam os brancos. Talvez até conseguissem seus direitos por estarem em maior quantidade. Mas, em compensação, será que seriamos tão resistentes as provações, como é a população afro-descendente de nosso país?

Apesar do baixo número de produções textuais entregues é fácil aferir que conseguiram notar "a história trocada", para ser "mais evidente a presença do racismo na sociedade brasileira"11. Não tivemos como fazer esta análise para o oitavo e o nono ano, por falta de produções textuais que minimamente representasse as salas de aula. $O$ trabalho efetuado pelo docente em sala de aula possibilitou aos alunos rever a história no Brasil, mas os indícios que nos chegaram são insuficientes para conjecturarmos em que medida o aprendizado foi "significativo" (Rüsen, 2012) entre eles.

\section{Os movimentos da literatura brasileira e o respeito às diferenças}

${ }^{11}$ Aluno do oitavo ano, não se identificou no texto. 
A Moreninha é feia e o navio com os escravos é sujo, pra que estudar isso? 12

As discussões efetuadas pela disciplina de Lingua Portuguesa foram centralizadas em pontos da literatura brasileira dos séculos XIX e XX. O objetivo era fazer os alunos pensarem o poema de Castro Alves, Navio Negreiro, e observar se, ao fazerem isso, conseguiam elaborar correspondências com as cenas do filme Amistad, trabalhado pela disciplina de História. Com $A$ moreninha, de Joaquim Manuel de Macedo, publicado em meados de 1840, a meta era ver se os discentes faziam comparações com a situação apresentada em Navio Negreiro, e se, ao mesmo tempo, notavam as nuances com Quilombo e Xica da Silva, vistos na disciplina de História. Em Dom Casmurro, de Machado de Assis, produzido no final do século XIX, além de verificar se os alunos acompanhavam a dinâmica das discussões propostas, era verificar se conseguiam também observar correspondências com as outras disciplinas. As situações apresentadas em Macunaíma, de Mário de Andrade, publicado no final dos anos 1920, e, depois, com Cidade de Deus, de Paulo Lins, publicado em meados dos anos 1990, além de possibilitarem aos alunos ver as relações entre os romances e suas adaptações para o cinema, também serviam para observarem movimentações, desafios e percalços vividos pelos afrodescendentes na literatura brasileira, depois representados no cinema.

Antes, porém, de adentrar na leitura de fragmentos selecionados do poema e dos romances, além das cenas dos filmes, pediu-se aos alunos para contarem um pouco de sua história de vida e a de alguém que admiram. O resultado alcançado nesta primeira etapa foi muito rico, diversificado e promissor (infelizmente não temos como pormenorizá-lo neste espaço). Havia desde alunos que mostravam certa predisposição para a elaboração de boas tramas narrativas, ao contarem suas histórias e a de familiares, como aqueles que não faziam questão alguma de falarem sobre si mesmos ou de conhecidos. Para 9a2, negro, “o preconceito ronda cada esquina que a gente passa, só não

${ }^{12}$ Aluno do sétimo ano, não se identificou em sua produção textual. 
vê quem não quer"; ao passo que 7a20, negro, "ser negro nesse país é muito difícil, por causa que só os de cor pode dizer o efeito que causa o racismo".

Quando adentramos as produções textuais, verifica-se que a maioria dos alunos do sétimo ano (17) não notou a correspondência entre a feiura inicial de Carolina (a Moreninha), em função de sua cor de pele, enquanto só em 2 casos os discentes ressaltaram tal ponto. Para $7 \mathrm{a}$, branco, a "Moreninha fala sobre uma menina chamada Carolina, conhecida como Moreninha", que viveu "um romance com Augusto, só que no começo ele não gostava dela por ser negra". Com certo julgamento valorativo 7a3, branca, viu "Augusto achando Carolina uma negra feia e desagradável", que só pelo típico desenlace amoroso "ficaram juntos no final do romance". Ao mesmo tempo, a maioria dos alunos (15) percebeu as condições indignas aque foram sujeitado os africanos capturados na África para serem escravizados no Brasil, sofrendo evidentes maus tratos durante a travessia.

Os alunos do oitavo ano em sua maioria (15), não notaram a relação da feiúra e indispliscência de Carolina com a sua cor de pele; apenas 3 ressaltaram esse fato. Para 8a1, parda, o romance "A Moreninha, cujo nome é Carolina, é morena e por conta de sua cor nunca fora notada por Augusto", mas quando ele "começou a notar sua beleza por dentro, a cor passou a deixar de ser um problema, e se declarou para ela". A discente observa ainda que:

[...] o poema Navio Negreiro conta os sofrimentos dos escravos desde o momento de sua captura na África e os horrores que viviam nos navios ao virem para o Brasil, em completa situação de imundície e maus tratos, até o momento em que viviam os dramas do cativeiro nas fazendas.

A relação construída pela discente entre os dois textos é muito interessante, ao notar que, "apesar de Carolina não ser escrava, ela viveu de perto muitas situações que eram comuns aos escravos negros descritos no poema". Porém, mesmo que a maioria dos discentes (10) tenha enfatizado a captura, a venda e o trabalho escravo do negro, e 8 não se tenham dado conta disso com clareza, apenas aquela discente conseguiu pontuar correspondências entre os dois.

A maioria dos alunos (16) do nono ano que entregaram as narrativas (já que tivemos 19 dos 31 alunos) conseguiu perceber o processo de captura 
e escravização dos negros na África, as consequências do tráfico e a condição precária das embarcações que fazia muitos deles adoecerem e morrerem em alto-mar. Eles notaram o amor proibido retratado em A Moreninha, mas não identificaram que o principal motivo desta proibição se devia à condição socioeconômica e à cor de pele da protagonista. Eles tiveram grande sensibilidade ao observar as peculiaridades da trama, inclusive, sobre Augusto achar Carolina feia, e somente depois de conhecê-la teve seu julgamento inicial alterado, ao perceber que passou a sentir algo pela moça. Para 9a4, branca, a Moreninha é:

[...] um romance entre uma menina apelidada de moreninha e um menino chamado Augusto, que tinha ido com Fabrício e Leopoldo à casa da avó de Felipe, cuja irmã se chamava Carolina: a Moreninha.

Para ela, no "começo do livro eles não sentem nada um pelo outro; porém, no decorrer da história, eles vão se apaixonando". A mesma aluna, ao observar o poema nota que é "um retrato de um negro escravizado na África que estava num navio rumo a uma terra desconhecida onde seriam escravos de um senhor". Não apenas isso; também são relatados "os sofrimentos das mulheres e das crianças, o espancamento dos homens, as más condições a que eram submetidos, como: fome, sede, doenças e até a morte”, razão por que "muitos morriam lá por causa dos maus tratos".

Em relação a essas questões, 9a22, parda, escreve:

A história do navio negreiro foi uma versão da realidade; Castro Alves não a inventou. Ele criou o poema Navio Negreiro justamente para contar o que os negros tiveram que enfrentar, e as lutas que tiveram que encarar. Não tinha alimento suficiente para todos na embarcação, a água era escassa, as roupas precárias, nem sequer o ar que respiravam nos porões do navio era puro. Mulheres e crianças também passaram por essa luta, já que eram acorrentados e açoitados como os homens, em salas escuras do navio, ou mesmo no convés, para que todos vissem o que acontecia com quem não obedecia. Quando chegavam ao seu destino eram preparados para serem vendidos pelo melhor preço possivel e irem trabalhar como escravos nas plantações.

As observações feitas pelos alunos do nono ano convergiam, em muitos aspectos, com as do sétimo e oitavo ano. Note-se ainda que a interpretação construída pelos discentes se assemelhou a proposta de Ynaê Lopes Santos (2017), para o estudo da história da África e do Brasil afrodescendente em sala de aula. Diz ela a respeito: 
Após a longa travessia [...] quando finalmente desembarcavam nos portos da América Portuguesa, a situação de boa parte dos africanos era péssima. Aqueles que tinham conseguido aguentar a viagem passavam por um breve exame médico e eram rapidamente vendidos (Santos, 2017, p. 174).

O trabalho efetuado pela docente em sala de aula contribuiu para que os alunos começassem a olhar com maior atenção e sensibilidade para a literatura brasileira e percebessem que além dos floreios e da retórica, havia também uma visão política e social presente nos textos dos romancistas. Isso apareceria em Dom Casmurro, Macunaima e Cidade de Deus. Não temos como aferir com maior precisão esse momento da aprendizagem porque não dispomos de material escrito pelos alunos.

\section{Percepção da cultura africana e afro-brasileira nas manifestações artísticas}

A arte africana envolve o colorido, a ousadia e a religião, mas não sei explicar muito bem como tudo isso se relaciona, e como está distribuído no continente. ${ }^{13}$

A disciplina de Artes teve como objetivo traçar um panorama da produção e das manifestações artísticas e culturais da África e do Brasil, com a intenção de mostrar as proximidades e as diferenças entre elas, tanto no passado, quanto no presente. O trabalho desenvolvido pela disciplina em sala de aula mostra um pouco da percepção dos alunos a respeito da cultura africana e da afro-brasileira, e suas manifestações artísticas. O material que foi apresentado pelos alunos do sétimo ano indica, num primeiro momento, que poucos conhecem a produção artística do continente africano e suas relações para a formação da produção e manifestações artísticas afrobrasileira. Quando questionados sobre o que sabiam sobre a arte africana, 9 alunos apontaram que não sabiam quase nada; 5 conseguiam reconhecer a diversidade, a riqueza e a pluralidade da produção e manifestações artísticas da África. Apenas 1 aluno conseguiu dar exemplos, relacionando passado e

${ }^{13}$ Aluno do oitavo ano, não se identificou na produção textual. 
presente, e diferenciar suas manifestações no tempo e no espaço. Neste último ponto, veja-se o caso de 7a16, branca, que diz:

A arte africana representa os usos e costumes das tribos africanas distribuídas pelo continente. O objeto da arte lá praticada são os homens, os animais e a natureza. Ela expressa muita sensibilidade nas pinturas corporais e nas máscaras e esculturas, que estão muito relacionadas à comunidade, por isso são tão diferentes umas das outras. O que se produz num local, não é igual ao que se faz em outro. A riqueza é enorme, mas eu ainda sei muito pouco sobre ela.

Ao se observar o que dizem saber sobre a arte afro-brasileira, as respostas não diferem muito. Até porque 10 dizem não saber quase nada; 4 conseguiram mostrar um pouco da riqueza das manifestações artísticas, e apenas 1 avançou na análise. Neste caso, a mesma aluna escreve:

A arte afro-brasileira foi iniciada com a vinda dos escravos negros da África para o Brasil, que foram se miscigenando com a cultura local índia e portuguesa. Mas foram os seus descendentes que trouxeram a marca das manifestações artísticas e culturais afro-brasileiras, com a capoeira, o carnaval, a ginga para o futebol, as misturas religiosas e culturais que fazem de nós brasileiros um povo tão rico, e ao mesmo tempo tão pobre. Rico nas roupas, cores, pinturas, tradições africanas. Pobre por não respeitarmos essas manifestações artísticas, discriminarmos àqueles que a manifestam, os afro-descendentes, e não reconhecermos que é isso que faz de nós brasileiros.

A relação que $7 \mathrm{a} 9$, parda, fez dessas questões também nos chamou atenção, porque para ela a "arte africana representa os usos e costumes das tribos africanas", que são representadas nas "pinturas no rosto, com as máscaras e as esculturas, o colorido das roupas e das danças". Quando, porém, teve que pensar a arte afro-brasileira, apenas indicou que é "a dos descendentes brasileiros". As situações em que os alunos identificavam certas características da arte africana, mas não conseguiam fazer o mesmo em relação à afro-brasileira, ou notar o que as ligava, não eram exclusividade dos alunos "pardos"; também ocorriam entre os "brancos". A aluna 7a11, parda, assim se posiciona nestas questões: "não sei quase nada, mas imagino que seja composta por esculturas no barro, pinturas abstratas e corporais", dizia isto da arte africana. Em nova referência que trata da arte afro-brasileira, a aluna acrescenta: "novamente não sei muito, mas suponho que seja uma arte baseada nos afro-descendentes, que viveram e vivem agora no Brasil, e deve retratar as culturas misturadas". Isso mostra que para além das dificuldades ela conseguia indicar as relações entre as artes e as culturas. 
O trabalho docente em sala de aula foi fundamental para ampliar a compreensão dos alunos sobre a arte e as manifestações culturais, africana e afro-brasileira, possibilitando a elaboração de pinturas, máscaras e desenhos, que foram expostos na escola durante a semana da "consciência negra".

Ao nos deparar com o resultado do trabalho efetuado no oitavo ano, surpreendeu-nos que os alunos não atingissem os mesmos resultados iniciais do sétimo. Quando questionados sobre o que sabiam sobre a arte africana, 10 alunos disseram não saber quase nada; 3 conseguiam reconhecer a diversidade, a riqueza e a pluralidade da produção e manifestações artísticas da África. Nenhum dos alunos, porém, conseguiu dar exemplos, relacionando passado e presente, e explorando a variedade das manifestações artísticas. Resultado semelhante a respeito das manifestações artísticas e culturais afrobrasileiras, com 10 alunos informando que sabiam muito pouco e apenas 3 conseguindo reconhecer um pouco da diversidade e da riqueza. Mais do que apenas surpreender, foi o resultado do trabalho docente de nada ter conseguido acrescentar. Muitos chegavam mesmo a admitir, como 8a8, pardo, que "não sei quase nada, é coisa de indígena?". Ou, ainda, 8a18, branco: "não sei quase nada, só que é entediante". Em relação a arte afro-brasileira, o mesmo aluno assevera: "nada, absolutamente nada".

Não nos foi possível avaliar o nono ano. É certo afirmar que o resultado parcial alcançado na disciplina se deveu ao pouco tempo disponibilizado para tratar da temática em sala de aula. Mas isto, por si só, não explica os resultados parciais alcançados. É possível ao menos inferir que o sétimo ano teve mais interesse e disposição que o oitavo. Se isso foi resultado do calendário escolar das provas, da dificuldade de o docente trabalhar com as turmas, ou apenas desinteresse dos estudantes, não tivemos material suficiente para dirimir tal afirmação.

\section{A distribuição geográfica das diferenças étnico-raciais e culturais}


A África é um país, né? ${ }^{14}$

A disciplina de Geografia tinha como objetivos identificar as diferenças espaciais, socioeconômicas e culturais do continente africano; estabelecer um panorama da geografia do tráfico de escravos no século XIX ${ }^{15}$ e mostrar aos discentes a relação da escravidão com a produção de bens e produtos no Brasil. Após serem traçados esses panoramas o docente deveria mostrar as especificidades da escravidão no estado de Mato Grosso (e Mato Grosso do Sul), estado que se registrou tanto a escravidão indigena, quanto a escravidão negra. Por fim, enfatizar que o município de Paranaíba, criado no século XIX, também teve trabalho escravo e fazia parte das rotas comerciais do período, por estar entre os atuais estados de Mato Grosso, Goiás, Minas Gerais e São Paulo. Com o uso do Atlas geográfico de Mato Grosso do Sul e seus municípios, produzido por Valter Mangini de Barros e publicado em 2017, o docente pôde mostrar aos alunos a distribuição geográfica dos 79 municípios do estado, suas peculiaridades regionais e especificidades históricas - infelizmente, não houve tempo para os alunos produzirem a pesquisa integrante do projeto, que era observarem em que municipios houve escravidão no Estado e o tipo de escravidão (negra, indigena, ou ambas), e apresentarem os resultados das pesquisas que fizeram sobre o bairro onde moram.

Apenas os alunos do oitavo ano entregaram suas produções textuais. Com elas, foi possivel observar que 13 alunos conheciam muito pouco do continente africano; 3 nada conheciam e somente 2 apresentavam maior propriedade de detalhes em suas respostas. Para 8a4, branca:

Não sei muitas coisas sobre o continente africano, mas imagino que é repleto de animais, como eu vejo nos documentários. Deve ser muito quente, com desertos, e outras regiões cheias de florestas e vegetações nativas. Há camelos, leões, girafas, e outros bichos. Muitos negros e poucos brancos, mas é os brancos que mandam, né? Pouca água e muitas crianças passando fome. Países muito ricos, e outros muito pobres.

Já para 8a16:

O continente africano tem várias regiões, etnias e culturas diferentes. Convive com riqueza e pobreza ao mesmo tempo, mesmo com países ricos e outros pobres. Há países ricos com minerais preciosos e outros muito

${ }^{14}$ Resposta de questionário de aluno do oitavo ano, mas sem identificação.

15 Para um estudo pormenorizado do tráfico de escravos no Atlântico, ver: Klein, 2004. 
pobres, com crianças morrendo e muitas pessoas passando fome. Vários animais diferentes, como: girafa, elefante, coiote.

Não nos foi possivel avaliar os acréscimos que os alunos tiveram com o trabalho docente realizado em sala de aula, entre outras razões, por só termos obtido material do oitavo ano. Mesmo neste caso, não tivemos as produções textuais relativas à finalização das atividades do docente, não sendo por isso possivel pormenorizar tais questões e avançar na análise.

\section{As tramas que se entrelaçam em uma colcha de retalhos soltos}

Foi bom falar de nossas vidas, isso nos ajudou a nos conhecer mais, mas ruim lembrar-se dos velhos tempos, cheios de violência, dor e morte. ${ }^{16}$

Depois de construirmos um breve painel a respeito dos resultados obtidos pelo trabalho disciplinar efetuado pelos professores, junto com os discentes do sétimo, do oitavo e do nono ano, é preciso agora retomar as linhas que interligavam o trabalho interdisciplinar proposto à aplicação do ensino da cultura e história africana e da afro-brasileira nos moldes da Lei n. 10.639/03.

O resultado obtido com o questionário final para encerrar as atividades realizadas em sala de aula permite pensar algumas situações de aprendizado para alunos do sétimo e do nono ano, já que não tivemos nenhum questionário entregue pelos alunos do oitavo. No sétimo ano foram entregues 15 e no nono 14, totalizando 29 questionários (dos quais 3 em branco e 6 parcialmente respondidos).

A maioria dos alunos do sétimo ano (11) conseguiu observar os efeitos da escravidão sobre os negros do passado e os afro-descendentes do presente, o que, entre outras coisas, refletia situações hierárquicas condicionadas por questões socioeconômicas, e laços de sociabilidade caracterizados, dentre outros fatores, por distinções como a cor de pele, que era apenas um dos requisitos para ser ou não incluído entre "os homens (e mulheres) de bem" de

16 Resposta de questionário de aluno do nono ano, mas sem identificação. 
nossa sociedade. Da escravidão, ainda que ocultos ou implícitos, sobrevivem resquícios deste estigma nas formas de tratamento, no racismo nem sempre admitido pelas pessoas, na relação entre negro e criminalidade, na baixa escolaridade e em salários menores entre os afro-descendentes (Cf. Guimarães, 1999, 2000, 2004, 2006).

Em face destes pontos, 7 a11, que consta como parda nos registros, mas se declara "morena, realista, sem paciência, boa conselheira, atenciosa, ciumenta e muito bipolar", observa que "a discriminação existe desde muito tempo atrás e influencia muito nossa atualidade, mas o racismo vem diminuindo, felizmente" e "os negros foram e são importantes na história do Brasil". Para ela, nas "aulas de História quando o conteúdo passou a ser sobre a escravidão, e também com os trabalhos sobre consciência negra, pude entender melhor as nuances da história do Brasil". O uso de "vídeos, músicas e textos pelos professores ampliou muito meu conhecimento sobre os negros e os afro-descendentes", e ver o "quanto sofreram e sofrem até hoje, me ajudou a melhorar minha visão do mundo, a visão de que somos todos importantes e deviamos ser tratados igualmente, pelo que fazemos, não apenas por nossa cor de pele". Ao ver assim nossa história percebemos "que todos nós, brancos, negros, pardos e índios, somos muito importantes, porque foram todos que ajudaram a construir nosso país e fazer do Brasil o que ele é hoje". Portanto, isso nos mostrou, que "não deveria ter etnocentrismo, que gera o racismo, o preconceito e a discriminação; se todos nós fomos e somos responsáveis pela construção do Brasil, e formamos juntos a sociedade brasileira, por que uns têm que valer mais do que outros, em função de sua cor de pele e dinheiro no bolso?".

Referindo-se a estas questões, 7a9, que consta como parda, mas que se diz "morena", e que se acha "uma pessoa meio calma, por que às vezes eu sou meio grossa, quando deveria ser mais altruísta", vê que o racismo "é muito chato, quem faz isso não tem futuro, não tem amor, nem compaixão". Para ela, o "negro foi muito importante; as pessoas que desrespeitam os negros pela sua cor não sabem o que é o amor", e o trabalho realizado em sala de aula trouxe "um respeito muito grande; aprendemos que não respeitar o negro só 
por causa de sua cor é muita burrada". Também vimos situações em que o afro-descendente não se percebia no interior de um processo histórico, que diretamente se reflete na forma pela qual as pessoas o reconhecem ou não. $O$ aluno 7a20, negro, e se declarou "negro, tranquilo, mas não preguiçoso como os outros acham de nóis". Para ele, "tudo bem que eu não ligo muito para isso; eu acho errado; vejo como os outros sofre, mas comigo isso quase não acontece". Além disso, "eu gosto da minha cor, de ser negro, mesmo a história do negro tendo sido bem ruim".

E os alunos "brancos", o que dizem? Para 7a13, branca (não declarou sua cor no questionário), diz que “os negros foram muito importantes na formação da sociedade brasileira, mas foram muito discriminados por sua cor", e foi esse ano que "a gente viu melhor o lado dos negros e a gente não tinha visto ainda o lado deles, e como os europeus foram muito escrotos com os negros"; porém, a "história é realmente muito pesada e dava até vontade de chorar; agora sei por que não ensinam muito essa história". A discente não avançou nesse raciocínio em sua produção textual.

Com os alunos do nono ano, vimos também que a maioria (11, dos 14) percebeu a importância de se estudar a história e a cultura africana e a afrobrasileira. Para 9a8, que consta nos registros como branca, diz: "sou parda; quando me estresso choro e fico vermelha". Para ela, os "negros sofreram muito, mas conseguiram superar a dor com a liberdade”. Diz, ainda, que ver os amigos compartilharem suas histórias foi muito bacana, mas as perguntas sobre "a história do Brasil era muito dificil e não [foi] legal". Todavia, com o trabalho desenvolvido pelo "professor de História eu vi questões da história do Brasil que desconhecia, mas não gostei das aulas dele, de Português gostei muito de compartilhar nossas histórias, Geografia e Artes não houve quase nada".

Vemos com 9a23, que aparece como branca e assim se declara, que "o racismo sempre esteve presente na história do Brasil, e está presente até hoje”. No entanto, não se reconhece em nossa sociedade que o "chão que a gente pisa foi construído com o suor e o sangue dos negros escravizados, por isso, nós deviamos dar mais oportunidades para eles e respeitá-los pelo que eles 
fizeram". Com o trabalho, "nós adquirimos mais conhecimento sobre a escravidão e o preconceito". Com isso "podemos melhorar nosso aprendizado, ajudar quem precisa e respeitar as diferenças". Note-se, que o estigma da cor pairou sobre alguns alunos, como 9a17, que aparece nos registros como branco, mas se declarou "moreno, mesmo estando bravo e com vergonha de dizer". No trabalho vimos que os "negros tinham que fazer tudo que seu 'chefe' mandava", e penso que "eles ainda são desprezados em nossa sociedade".

Sobre o que foi até aqui apresentado, é possível refletir com Rüsen (2010) que houve aprendizado "significativo", mas, infelizmente, percebido apenas por alguns alunos. Como fazer para tornar o ensino mais promissor e presente junto a um número maior de educandos? ${ }^{17}$ Elaboramos alguns princípios, que propomos à reflexão de docentes, pais e filhos:

1. Pensa-se muito mais nas notas, quando o mais importante é o aprendizado.

2. Pensa-se em passar o conteúdo, mas esquece-se de ver a compreensão.

3. Escolas e professores prendem-se a resultados, mas deixam de lado o processo de ensino.

4. Vê-se muito mais o ter, enquanto se deixam de lado o ser e suas múltiplas formas de estar no mundo.

5. Mostramos que a escola é uma prisão, um refúgio, e não um espaço de formação para os alunos.

Como podemos mudar essa situação? Para começar, já que esse tipo de mudança também é processual, lenta e gradual $^{18}$, os pais devem:

1. mostrar aos seus filhos que eles são importantes;

2. ensinar-lhe a olhar para a vida e o mundo, não só para si mesmos;

3. dizer-lhes que são capazes;

4. dar-lhes exemplos concretos e que thes sejam próximos;

5. mostrar-lhes que o respeito é mais importante que a violência;

6. e que a educação pode transformar a sua vida, mas isso exige tempo e dedicação permanente.

\footnotetext{
${ }^{17}$ Convém aqui salientar que para Daniel Barros (2018), em País mal educado, entender e superar os péssimos índices de aprendizado escolar dos alunos e das alunas do Ensino Fundamental II no Brasil é nosso maior desafio, inclusive, para tornar nosso país menos desigual.

${ }^{18}$ Considerando que: "Educar não é modificar a mente dos educandos, mas levá-los a desenvolver consciência crítica; não é cobrar demais, mas conduzi-los a ter autonomia; não é superproteger, mas estimulá-los a trabalhar perdas e frustrações; não é dar broncas ou punir, mas levá-los a ter autocontrole e colocar-se no lugar dos outros" (Cury, 2017, p. 8-9).
} 
Aos alunos é importante que saibam, como nos diz Freire (2011), que:

1. o respeito é uma conquista e o aprendizado um processo longo e desafiador;

2. aprender pode ser tão divertido quanto uma brincadeira, mas é preciso saber como jogar;

3. o professor não é tio, pai ou mãe, mas um profissional que deve ser respeitado pelo que faz;

4. enquanto aprende, o aluno também ensina, e quem ensina também aprende;

5. é somente quando o gosto pela leitura o contagia, que ele realmente começa a aprender a ler e a conhecer o mundo, as coisas e as pessoas;

6. sem paciência não há aprendizado, e sem respeito não há como construir a alteridade;

7. a escola não é uma prisão, mas também não possui todas as soluções para sua vida;

8. há tempo para tudo se ele souber usar bem o tempo que tem.

Todos os princípios aqui esboçados pretendem tornar o aprendizado “significativo" (Rüsen, 2010) para os alunos. Para que isso aconteça, porém, é preciso que os discentes sejam protagonistas de sua formação educacional, sabendo que: a) os erros são importantes, mas apenas quando se aprende com eles, preparando-se para acertar; b) que o fracasso também pode ensinar, quando não se tiver medo de encará-lo de frente; c) nem só de talento é feito o saber, mas muito mais de esforço e da dedicação diária. Vimos, com o ensino da história e da cultura africana e afro-brasileira, que ensinar é desafiador; mas quando abraçamos o desafio, o processo pode se tornar encantador para os alunos, prazeroso para os docentes e propiciador da formação para os cidadãos (Carvalho, 2001), desde que saibam respeitar as diferenças étnicoraciais e culturais da sociedade brasileira.

\section{Conclusões}

Eu admiro muito minha mãe, por ser uma mulher guerreira, trabalhadeira, honesta e com uma felicidade inabalável, apesar das adversidades da vida. Afro-descendente, desde sua infância sempre foi independente, uma mulher séria, mãe de familia sempre muito educada. Quando era pequena sofreu preconceito por falta de condições financeiras e não teve o apoio e cuidado de seu pai, mas mesmo assim conseguiu ser muito feliz (9a28, parda). 
Após mais de dez anos de aprovação da Lei n. 10.639/03, é possível afirmar que somente em parte ela foi inserida no cotidiano do trabalho escolar (Gomes, 2012, 2012b). Não são todas as escolas do país que trabalham de forma interdisciplinar. As que trabalham encontram dificuldades na execução plena dos conteúdos, em função de problemas de alinhamento de metas e pontos a serem distribuídos e tratados disciplinarmente entre História, Língua Portuguesa (Literatura) e Artes (Gomes, 2012; Roiz, Santos, 2018). A maioria das escolas quando trabalha com essas questões o faz de forma disciplinar, sem que haja correlação com outras disciplinas ao longo do ano letivo. Há situações em que o trabalho é bem sucedido no ensino médio, mas não no fundamental (Gomes, 2012; Borges, 2016; Leme, 2018). Já em outros casos, embora oferecido no ensino fundamental, o ambiente não é tão propício no ensino médio (Gomes, 2012; Roiz, Santos, 2018b). Poucas escolas técnicas se preocupam em trabalhar com a lei em seu quadro curricular e disciplinar (Leme, 2018). Em muitas situações a justificativa para o descaso e a falta de compromisso com a execução da lei está em que tanto direções, quanto coordenações, não se empenham em fazer um trabalho articulado com o quadro docente (Borges, 2018; Roiz, Santos, 2018). Em outras, a justificativa está em que não existe material didático adequado para ser usado em sala de aula. Mesmo considerando os existentes (como o Kit A cor da cultura, produzido em 2003), são insuficientes para se executar um trabalho interdisciplinar nas escolas (Gomes, 2012; Roiz, Santos, 2018).

Evidentemente, ainda faltam estudos sistemáticos para que se possa oferecer um painel compativel com a realidade dos trabalhos executados nas escolas municipais e estaduais, públicas e privadas, distribuídas pelo Brasil (Gomes, 2012, 2012b). Os que se dispõem ainda não adotam como regra a interdisciplinaridade entre matérias como História, Língua Portuguesa (Literatura) e Artes e os conteúdos relativos à história e a cultura africana e a afro-brasileira. Assim fazendo, tornam inconsistentes as tentativas de implementação da lei 10.639/03 em sala de aula, cuja meta é combater o racismo, o preconceito e a discriminação, na mesma medida em que se propõe oferecer os esclarecimentos necessários para que os educandos possam 
respeitar plenamente as diferenças étnico-raciais e culturais da sociedade brasileira (Gomes, 2012).

A aplicação da proposta de se trabalhar de forma interdisciplinar as referidas disciplinas de História, Lingua Portuguesa (Literatura) e Artes, junto com a de Geografia, tem comprovado ser cada vez mais pertinente e consistente. O uso de cenas de filmes e letras de músicas torna as aulas mais dinâmicas, contribuindo para maior participação dos alunos. Correlacionar conteúdos discutidos entre as diferentes disciplinas, permite que o aprendizado seja "significativo" (Rüsen, 2010), mesmo considerando que apenas uma pequena parcela dos educandos cumpra tal etapa. Vimos que apenas uma parte dos alunos consegue relacionar "o presente com o passado" e "o passado com o presente"; uma outra parte alcança apenas uma dessas etapas, e um pequeno percentual não atinge esta meta. Observamos maior propensão em se manter a "consciência histórica" de tipo tradicional e exemplar ao longo do trabalho realizado, e apenas uma pequena parte dos alunos conseguia se movimentar entre a crítica e a genética - mas o material de que dispomos foi insuficiente para inferir mais do que permitem tais indicios. O trabalho, neste formato, permite obter resultados mais consistentes em relação ao combate ao racismo, ao preconceito e à discriminação, por meio da conscientização dos educandos quanto ao respeito às diferenças étnico-raciais e culturais, vindo a possibilitar a formação de cidadãos que convivem numa sociedade diversificada e híbrida - cultural, econômica e socialmente plural - como é a brasileira (Carvalho, 2001; Guimarães, 1999, 2004).

\section{Referências Bibliográficas}

APPLE, M. W. Ideologia e currículo. $3^{a}$ Edição. Porto Alegre: Artmed, 2008.

BARROS, D. País mal educado: por que se aprende tão pouco nas escolas brasileiras? Rio de Janeiro: Record, 2018.

BORGES, M. F. M. O ensino de história e cultura africana e afro-brasileira na perspectiva da lei 10.639/03: análise de politicas públicas na EE. Prof. Hélio Palermo, cidade de Franca/SP. 2016. Dissertação (Mestrado em Planejamento 
e análise de Políticas Públicas) - Universidade Estadual Paulista Júlio de Mesquita Filho.

CARVAlHo, J. M. Cidadania no Brasil: o longo caminho. Rio de Janeiro: Civilização Brasileira, 2001.

CERRI, L. F. Ensino de história e consciência histórica: implicações didáticas de uma discussão contemporânea. Rio de Janeiro: FGV, 2011.

CHARLOT, B. A mistificação pedagógica: realidades sociais e processos ideológicos na teoría da educação. São Paulo: Cortez, 2013. 2013b.

Da relação com o saber às práticas educativas. São Paulo: Cortez,

CURY, A. 20 regras de ouro para educar filhos e alunos: como formar mentes brilhantes na era da ansiedade. São Paulo: Planeta, 2017.

DOMINGUES, P. O movimento negro brasileiro: alguns apontamentos históricos. Tempo, Rio de Janeiro, v. 12, n. 23, 2009, p. 100-122. Link: http://www.scielo.br/pdf/tem/v12n23/v12n23a07.pdf.

GILROY, P. Entre campos: nações, culturas e o fascinio da raça. SP: Annablume, 2007.

GOMES, F.; DOMINGUES, P. (Org.). Politicas da raça: experiências e legados da Abolição e da pós-emancipação no Brasil. São Paulo: Selo Negro, 2014.

GOMES, N. L. (Org.) Práticas Pedagógicas de trabalho com Relações ÉtnicoRaciais na Escola na perspectiva da Lei 10.639/03. 1a. ed. Brasília: MEC/UNESCO, $2012 . \quad$ Link: http://unesdoc.unesco.org/images/0026/002605/260516POR.pdf.

- Relações étnico-raciais, educação e descolonização dos currículos. Currículo sem fronteiras, v. 12, n. 1, 2012b, p. 98-109. Link: http://www.acaoeducativa.org.br/fdh/wpcontent/uploads/2012/11/curr\%C3\%ADculo-e-rela\%C3\%A7\%C3\%B5esraciais-nilma-lino-gomes.pdf.

GUIMARÃES, A. S. A. Preconceito e discriminação: queixas de ofensas e tratamento desigual dos negros no Brasil. São Paulo: Editora 34, 2004.

. Classes, raças e democracia. São Paulo: Editora 34, 2006.

. Tirando a máscara: ensaios sobre o racismo no Brasil. Rio de Janeiro: Paz e Terra, 2000.

. Racismo e anti-racismo no Brasil. São Paulo: Editora 34, 1999.

LEME, P. P. O uso de filmes nas aulas de história e cultura afro-brasileira e africana e sua influência na formação da consciência histórica em um curso de formação para o trabalho. Dissertação de mestrado em Educação, UEMS, 2018.

KLEIN, H. S. O tráfico de escravos no Atlântico. Ribeirão Preto/SP: Funpec Editora, 2004. 
NAPOLITANO, M. Cinema: experiência cultural e escolar. In: Secretaria de Educação, Estado de São Paulo. Caderno de cinema do professor dois. São Paulo: FDE, 2009, p. 10-31. Link: http: / / culturacurriculo.fde.sp.gov.br/administracao/Anexos/Documentos /3 20090708123643caderno_cinema2_web.pdf\#page $=7$.

ROIZ, D. S. Da "leveza" da adolescência ao "peso" de ser adulto: personalidade, profissão, religião e cidadania entre alunos do Ensino Médio de uma escola pública no interior do estado de São Paulo. Revista Interfaces da Educação, v. 7, n. 20, 2016, p. 41-64.

- Combatendo o racismo e respeitando as diferenças étnico-raciais: o ensino da história e cultura africana e afro-brasileira em sala de aula. Texto inédito, 2018, 27 págs.

. "Acaso ser diferente não pode ser também legal?"A "consciência histórica" de alunos do Ensino Fundamental II de uma Escola Estadual de Mato Grosso do Sul. Texto inédito, 2018b, 25 págs.

ROIZ, D. S.; SANTOS, J. R. A lei 10.639/03 e sua implementação em sala de aula. In: Roiz, D. S.; Gomes, G. F.; Ferreira, I. J. (org.) A (pós-)verdade numa época de mutações civilizacionais. Serra/ES: Milfontes, 2018, p. 297-334.

O uso de imagens no ensino da história e cultura africana e afrobrasileira nas salas de aula de escolas públicas de Campinas/SP. In: ROIZ, D. S.; SANTOS, J. R. (Org.) As leis na escola: experiências com a implementação das leis 10.639/03 e 11.645/08 em sala de aula. 1. ed. Jundiaí/SP: Paco Editorial, 2018b, p. 103-135.

ROIZ, D. S.; SANTOS, J. R.; TEIXEIRA, P. E. O uso de imagens para o ensino da cultura e história Africana e Afro-brasileira e a questão do racismo no Brasil. Educere et Educare (Impresso), v. 5, p. 209-230, 2010.

RÜSEN, J. Razão histórica. Teoria da História I: os fundamentos da ciência da história. Tradução de Estevão de Rezende Martins. Brasília: Ed. UnB, 2001.

. Reconstrução do passado. Teoria da história II: os princípios da pesquisa histórica. Tradução de Asta-Rose Alcaide. Brasília: Ed. UnB, 2007.

. História viva. Teoria da História III: formas e funções do conhecimento histórico. Tradução de Estevão de Rezende Martins. Brasillia: Ed. UnB, 2007b.

. Jörn Rüsen e o ensino de história. Organização de Maria Auxiliadora Schmidt, Isabel Barca e Estevão de Rezende Martins. Curitiba: Editora da UFPR, 2010.

Aprendizagem histórica: fundamentos e paradigmas. Curitiba/PR: W. A. Editores, 2012.

Cultura faz sentido: orientações entre o ontem e o amanhã. Tradução de Nélio Schneider. Petrópolis/RJ: Vozes, 2014.

- Teoria da história: uma teoria da história como ciência. Tradução de Estevão Rezende Martins. Curitiba/PR: Editora da UFPR, 2015. 
SANTOS, A. S. A lei n. 10.639/03 como fruto da luta anti-racista do movimento negro. In: Educação anti-racista: caminhos abertos pela Lei Federal $n^{\circ}$ 10.639/03. Secretaria de Educação Continuada, Alfabetização e Diversidade. - Brasília: Ministério da Educação, Secretaria de Educação Continuada, Alfabetização e Diversidade, 2005, p. 21-37. Link: http://www.acaoeducativa.org.br/fdh/wp-content/uploads/2012/10/saleslei-10.639-como-fruto-da-luta-antirracista.pdf.

SANTOS, Y. L. História da África e do Brasil afrodescendente. Rio de Janeiro: Pallas, 2017.

SCHMIDT, M. A.; GARCIA, T. M. F. B. (org.) Didática, história e manuais escolares: contextos Ibero-americanos. Ijuí/RS: Editora da Unijuí, 2013.

(org.) Recriando histórias a partir do olhar das crianças. Ijuí/RS: Editora da Unijuí, 2011.

2008.

(org.) Diálogos e perspectivas de investigação. Ijuí/RS: Editora da Unijuí,

- Contribuições para a discussão no campo da Didática: análise de resultados do projeto Recriando Histórias. 26reuniao.anped.org.br, 2003, 19 pags.

Link: http://revistas.umce.cl/index.php/contextos/article/viewFile/605/625. (versão publicada do relatório).

A formação da consciência histórica de alunos e professores e o cotidiano em aulas de História. Cadernos Cedes, Campinas, vol. 25, n. 67, p. 297-308, set./dez. $2005 . \quad$ Link: http: / /www.scielo.br/pdf/\%0D/ccedes/v25n67/a03v2567.pdf.

SCHMIDT, M. A.; BARCA, I. (org.) Aprender história: perspectivas da educação histórica. Ijuí/RS: Editora da Unijuí, 2009.

- (org.) Educação histórica: investigação em Portugal e no Brasil. Braga/Portugal: Editora da Universidade do Minho, 2009b.

. (org.) Jörn Rüsen: humanismo e didática da história. Curitiba/PR: W\&A Editores, 2015.

SCHMIDT, M. A.; URBAN, A. C. Passados possiveis: a educação histórica em debate. Ijuí/RS: Editora da Unijuí, 2014.

SOUZA, J. Subcidadania brasileira: para entender o país além do jeitinho brasileiro. Rio de Janeiro: LeYa, 2018.

. A elite do atraso: da escravidão à lava jato. Rio de Janeiro: LeYa, 2017. . A tolice da inteligência brasileira: ou como o país se deixa manipular pela elite. Rio de Janeiro: LeYa, 2015.

2011.

A ralé brasileira: que é e como vive. Belo Horizonte/MG: Ed. UFMG, 